\title{
Analysis of the 165 rRNA gene of micro- organism WSU 86-1044 from an aborted bovine foetus reveals that it is a member of the order Chlamydiales: proposal of Waddliaceae fam. nov., Waddlia chondrophila gen. nov., sp. nov.
}

\author{
Fred R. Rurangirwa, ${ }^{1,2}$ Pamela M. Dilbeck, ${ }^{2}$ Timothy B. Crawford, ${ }^{1}$ \\ Travis C. McGuire ${ }^{1}$ and Terry F. McElwain ${ }^{1,2}$
}

Author for correspondence: Fred R. Rurangirwa. Fax: +1 5093358529.

e-mail: ruvuna@vetmed.wsu.edu

Department of Veterinary Microbiology and Pathology ${ }^{1}$ and Washington Animal Diseases Diagnostic Laboratory2, Washington State University, Pullman, WA 99164-7040, USA

\begin{abstract}
The structural gene encoding the 165 rRNA of the new obligate intracellular organism presently designated WSU 86-1044' was sequenced and analysed to establish its phylogenetic relationships. The 165 rDNA sequence was most closely related to those of chlamydial species, having $84 \cdot 7-85 \cdot 3 \%$ sequence similarity, while it had $\mathbf{7 2 \cdot 4 - 7 3 \cdot 2} \%$ similarity with rickettsia-like organisms. When the sequences of the four species of chlamydiae (Chlamydophila psittaci, Chlamydia trachomatis, Chlamydophila pneumoniae and Chlamydophila pecorum) were compared, they had $>93 \%$ sequence similarity indicating that WSU 86-1044' was not close enough to be in the same family as current Chlamydiaceae members. However, based on the $84 \cdot 7-85 \cdot 3 \% 165$ rDNA sequence similarity of WSU $86-1044^{\top}$ and other previously described characteristics, WSU $86-1044^{\top}$ belongs to a novel family within the order Chlamydiales; hence, the proposal of Waddliaceae fam. nov., Waddlia chondrophila gen. nov., sp. nov.
\end{abstract}

Keywords: chlamydia, phylogeny, 16S rRNA, 16S rDNA sequence, abortion

\section{INTRODUCTION}

The organism WSU $86-1044^{\mathrm{T}}$, was originally isolated from tissues of a first-trimester aborted bovine foetus at the Washington Animal Disease Diagnostic Laboratory (Dilbeck et al., 1990). A cytopathic effect was observed within 2-3 d after the initial inoculation of bovine turbinate (BT) cell cultures with pooled spleen and liver homogenates. The organism was serially passaged numerous times and consistently induced cytopathic effect. It replicated rapidly to high levels, reaching peak titres exceeding $10^{8} 50 \%$ tissue-cultureinfective doses $\left(\right.$ TCID $_{50}$ ) per $\mathrm{ml}$ within $3 \mathrm{~d}$ (Dilbeck $e t$ al., 1990). Replication was inhibited by tetracycline, but not by penicillin or gentamicin (Dilbeck et al., 1990). Light microscopy revealed organisms within

Abbreviations: $\mathrm{BT}$, bovine turbinate; $\mathrm{TCID}_{50}, 50 \%$ tissue-culture-infective dose.

The GenBank accession number for the 165 rRNA gene sequence of WSU $86-1044^{\top}$ is AF042496. cytoplasmic inclusions that ranged in size from 0.2 to $0.4 \mu \mathrm{m}$ (Dilbeck et al., 1990). Electron microscopy confirmed that the organisms multiplied within a cytoplasmic vacuole with a developmental life cycle resembling that of erhlichiae and chlamydiae (Dilbeck et al., 1990; Kocan et al., 1990). The organisms occurred in two forms; a reticulated form found within a cytoplasmic vacuole, and a dense infective form that was released from the cells.

Presently, WSU $86-1044^{\mathrm{T}}$ is characterized as an obligate intracellular organism, which replicates within cytoplasmic vacuoles, exhibiting structural characteristics compatible with those of rickettsiae and chlamydiae (Dilbeck et al., 1990; Kocan et al., 1990). Serological identification of WSU $86-1044^{\mathrm{T}}$ was not successful as the organism did not react with monoclonal or polyclonal antisera to a variety of Rickettsia, Coxiella, Wolbachia, Anaplasma or Chlamydia spp. (Dilbeck et al., 1990). However, it did react weakly with antisera to Cowdria ruminantium. Thus, WSU 86$1044^{\mathrm{T}}$ has not been taxonomically classified. 
Progress in molecular biology using PCR and sequencing of DNA encoding 16S rRNA has enabled determination of the precise phylogenetic position of each bacterial species, particularly obligate intracellular bacteria which express few phenotypic characters (Hills et al., 1996; Roux \& Raoult, 1995). The primers are chosen from sequences that are highly conserved among the phylogenetic group referred to as the eubacteria (Wilson et al., 1990; Woese, 1987), but which are not found in eukaryotes, archaea or mitochondria. It is therefore possible to amplify only bacterial 16S rDNA sequences even in the presence of nucleic acids from other types of organisms. Because the nucleotide sequences found in 16S rDNAs vary in an orderly fashion throughout the phylogenetic tree, they have been useful for the study of molecular evolution (Woese, 1987). Thus $16 \mathrm{~S}$ rRNA or $16 \mathrm{~S}$ rDNA sequencing is one of the most powerful and precise methods for determining the distant as well as close (intrageneric) genealogical relationships of bacteria (Hills et al., 1996; Swofford et al., 1996; Woese, 1987).

In an effort to classify the agent WSU $86-1044^{\mathrm{T}}$, the DNA encoding the 16S rRNA was PCR-amplified and sequenced. Comparison of the $16 \mathrm{~S}$ rDNA sequence with other 16S rDNA sequences in GenBank indicated that WSU $86-1044^{\mathrm{T}}$ belonged to the order Chlamydiales. However, the similarity was not sufficient to allow its classification in any of the families within the order.

In a recent paper by Everett et al. (1999) on a revised classification scheme for the order Chlamydiales, Chlamydia pneumoniae, Chlamydia pecorum and Chlamydia psittaci were reclassified to Chlamydophila gen. nov. as Chlamydophila pneumoniae comb. nov., Chlamydophila pecorum comb. nov. and Chlamydophila psittaci comb. nov., respectively. Their new names will be used throughout this paper.

\section{METHODS}

WSU 86-1044'. The isolation of the organism from pooled foetal liver/lung homogenate has been described previously (Dilbeck et al., 1990). The organism was cloned at the 8 th passage by three serial limiting dilutions in 96-well plates of bovine turbinate (BT) cells (ATCC CRL-1390) (Dilbeck et al., 1990). Cloned organisms at the 13th passage in BT cells with a titre of $1 \times 10^{6 \cdot 2}$ TCID $_{50}$ were used in these studies.

DNA extraction. Genomic DNA was prepared from WSU $86-1044^{\mathrm{T}}$ passaged in bovine turbinate cells. The supernatants were harvested when the cytopathic effect was advanced and stored at $-70^{\circ} \mathrm{C}$. For use, the fluid was thawed and clarified at $500 \mathrm{~g}$ for $10 \mathrm{~min}$, and the organisms pelleted at $20000 \mathrm{~g}$ for $30 \mathrm{~min}$. DNA was prepared from the sedimented WSU 86-1044 ${ }^{\mathrm{T}}$ organisms using Puregene DNA Isolation Kit (Gentra Systems).

PCR amplification. The DNA encoding the 16S rRNA was amplified in vitro via PCR (White, 1993) by using a primer set (forward 5' AGA GTT TGA TCC TGG $3^{\prime}$ and reverse 5' TAC CTT GTT ACG ACT T 3') selected from the conserved sequences at the beginning and the end of the eubacterial kingdom 16S rDNA (Wilson et al., 1990; Woese, 1987).
PCR amplification was done in $100 \mu \mathrm{l}$ reaction mixture and Taq DNA polymerase from Gibco-BRL. Typically, a tube contained $10 \mu 10 \times$ PCR buffer made of $200 \mathrm{mM}$ Tris $/ \mathrm{HCl}$ (pH 8.4) and $500 \mathrm{mM} \mathrm{KCl}, 5 \mu \mathrm{l} 50 \mathrm{mM} \mathrm{MgCl}_{2}, 2 \mu 110 \mathrm{mM}$ dinucleotide mix (Invitrogen), $0.5 \mu \mathrm{l} 50 \mathrm{mM}$ of the reverse and forward primers, $79 \cdot 5 \mu \mathrm{l}$ double-distilled water, $2 \mu \mathrm{l}$ containing $0.25 \mu \mathrm{g}$ target DNA and $0.5 \mu \mathrm{l}(2.5 \mathrm{U})$ Taq DNA Polymerase. Before addition of the target DNA and Taq polymerase a wax gem (Perker-Elmer) was added to the tube and heated at $75^{\circ} \mathrm{C}$ for $5 \mathrm{~min}$ and then allowed to cool to room temperature. Amplification was performed in a GeneAmp PCR System 9600 Thermal Cycler (Perkin-Elmer) in which the target DNA was denatured by incubation at $95^{\circ} \mathrm{C}$ for 5 min followed by 35 cycles of denaturation $\left(94^{\circ} \mathrm{C}\right.$ for $1 \mathrm{~min}$ ), primer annealing $\left(55^{\circ} \mathrm{C}\right.$ for $\left.3 \mathrm{~min}\right)$ and primer extension $\left(72^{\circ} \mathrm{C}\right.$ for $\left.3 \mathrm{~min}\right)$. At the end of the cycling, the reaction mixture was held at $72^{\circ} \mathrm{C}$ for $7 \mathrm{~min}$ and cooled to $4^{\circ} \mathrm{C}$. The size of the PCR product was verified by agarose gel electrophoresis of $10 \mu \mathrm{l}$ reaction mixture (Sambrook et al., 1989).

Cloning, sequencing and sequence analysis. The amplified fragment was ligated into the EcoRI site of vector pCR 2.1 (Invitrogen) and used to transform Escherichia coli (oneshot cell INV $\alpha \mathrm{F}^{\prime}$ Competent Cells; Invitrogen). Individual, transformed colonies were grown in Luria Broth, DNA was isolated and then digested with $E c o$ RI. DNA fragments were separated in $1.5 \%$ agarose gel and stained with ethidium bromide to verify the size of the fragment ligated into the plasmid. Nucleotide sequencing of the recombinant inserts from selected colonies was performed by the Laboratory for Biotechnology and Bioanalysis, Washington State University, using the Perkin Elmer Applied Biosystems Prism Dye Terminator Kit and analysed on an ABI 373 DNA Sequencer. Cloning the amplified fragment into pCR 2.1 enabled sequencing of the whole amplicon, initially using M13 forward and reverse primers (Invitrogen) approximately 100 bases up- and downstream from the EcoRI cloning site, and subsequently with commercially synthesized specific primers (Life Technologies) selected as sequence information was obtained. Table 1 shows the primers used to sequence through the entire 16S rDNA amplicon of the WSU 86-1044 ${ }^{\mathrm{T}}$. Sequence analysis programs REFORMAT, GAP, REVERSE, PILEUP, DISTANCES, NEIGHBOR and GROWTREE in the University of Wisconsin Genetics Computer Group (GCG), version 8 (1994), were used for DNA analyses (Devereux et al., 1984). GenBank search for similarities was accomplished using BLAST and FASTA programs on-line (Pearson \& Lipman, 1988). Comparison of the WSU $86-1044^{\mathrm{T}}$ 16S rDNA sequence with published sequences of other organisms, most of which were obligate intracellular bacteria, was performed both by PILEUP and by DISTANCES analysis to calculate the Kimura two-parameter distances. Sequences of the following micro-organisms (GenBank accession no. and strain designation in parentheses) were compared: Chlamydophila (formerly Chlamydia) psittaci (M13769, strain 6BC $\mathrm{B}^{\mathrm{T}}$, Chlamydia trachomatis (M59178, strain 434 ${ }^{\mathrm{T}}$ ), Chlamydophila (formerly Chlamydia) pneumoniae (Z49873, strain TW-183 ${ }^{\mathrm{T}}$ ), Chlamydophila (formerly Chlamydia) pecorum (U73782), Simkania negevensis (L27666, strain $\mathrm{Z}^{\mathrm{T}}$ ), Parachlamydia acanthamoebae (Y07556, strain $\mathrm{Bn} 9^{\mathrm{T}}$ ), Rickettsia rickettsii (M21293, strain R), Cowdria ruminantium [X61659, strain Crystal Springs (Zimbabwe) isolate], Anaplasma marginale (M60313), Ehrlichia phagocytophila (M73220, strain OS ${ }^{\mathrm{T}}$ ) and Escherichia coli (M24996).

The neighbour-joining method and tree construction were 
performed by using the NEIGHBOR and GROWTREE programs, respectively. All sequences were aligned using the PILEUP multiple-sequence alignment program.

\section{RESULTS}

\section{PCR product}

Conserved eubacterial rDNA primers amplified a major WSU $86-1044^{\mathrm{T}}$ fragment slightly above $1.5 \mathrm{~kb}$. When the plasmid with the insert was isolated and digested with $E c o$ RI endonuclease, three fragments resulted comprising the vector pCR $2.1(3.9 \mathrm{~kb})$, one insert fragment slightly longer than $0.8 \mathrm{~kb}$, and a second insert fragment of approximately $0.7 \mathrm{~kb}$, indicating an internal EcoRI site in the amplicon. An EcoRI site at nucleotide positions 679-685 from the 5' of WSU $86-1044^{\mathrm{T}}$ was confirmed by sequence analysis. An EcoRI site also was reported approximately 680 nucleotides from the $5^{\prime}$ end of rDNA for Chlamydophila (formerly Chlamydia) psittaci (Weisburg et al., 1986). The sequence of Chlamydophila psittaci rDNA obtained from GenBank has an EcoRI site between nucleotides 681 and 687 .

\section{Sequences}

The sequence of the WSU $86-1044^{\mathrm{T}} 16 \mathrm{~S}$ rDNA consisted of 1526 nucleotides $(400 \mathrm{~A}, 300 \mathrm{C}, 453 \mathrm{G}, 333$ T). On-line BLAST and FASTA searches of GenBank for similar sequences revealed that WSU $86-1044^{\mathrm{T}}$ rDNA was $>80 \%$ similar to chlamydiae. The first 30 items of the search indicated similarity to the four known chlamydiae (Chlamydophila psittaci, Chlamydia trachomatis, Chlamydophila pneumoniae and Chlamydophila pecorum), small subunit of chlamydia rRNA, and to Simkania negevensis (Kahane et al., 1995; Everett et al., 1999). Similarity ranking by the Ribosomal Database Project (RDP) at the University of Illinois Urbana-Champaign Department of Microbiology indicated that the WSU 86-1044 ${ }^{\mathrm{T}}$ rDNA sequence was most similar to Chlamydophila psittaci.

\section{Phylogenetic analyses}

A new classification of the order Chlamydiales has been proposed in which the currently known strains with $>90 \% 16 \mathrm{~S}$ rRNA similarity form the Chlamydiaceae family. The chlamydia-like organisms which have $80-90 \% 16 \mathrm{~S}$ rRNA similarity form two new families: Simkaniaceae and Parachlamydiaceae (Everett et al., 1999). We compared 16S rDNA sequences of some members of the Chlamydiaceae, Simkaniaceae and Parachlamydiaceae (Everett et al., 1999), WSU 86-1044 ${ }^{\mathrm{T}}$, and some intracellular parasites from the Rickettsiaceae to assess their percentage sequence similarity. WSU $86-1044^{\mathrm{T}}$ exhibited the greatest similarity to members of the order Chlamydiales $(>84.5 \%)$. Three rickettsia species, which included Cowdria ruminantium, had values ranging from 72 to $72.9 \%$ while one Ehrlichia species had sequence similarities of $72 \cdot 1 \%$. The reported anti- genic cross-reactivity between WSU $86-1044^{\mathrm{T}}$ and Chlamydia ruminantium (Dilbeck et al., 1990) was not reflected in significant rDNA sequence identity.

\section{DISCUSSION}

Analysis of 16S rDNA of WSU $86-1044^{\mathrm{T}}$ indicated that the abortion agent was closely related to the members of the order Chlamydiales, having $84 \cdot 5-85 \cdot 3 \%$ sequence similarity. The relatively high degree of similarity of WSU $86-1044^{\mathrm{T}} 16 \mathrm{~S}$ rDNA to $16 \mathrm{~S}$ rDNA from the members of the order Chlamydiales provided justification for its inclusion in this group/order. However, when the rDNA sequences of four members from the family Chlamydiaceae were aligned they had sequence similarities of $93 \cdot 8-96 \cdot 7 \%$. Therefore the lower level of sequence similarity between WSU 86-1044 ${ }^{\mathrm{T}}$ and the members of the Chlamydiaceae family did not justify inclusion of WSU 86$1044^{\mathrm{T}}$ into this family (Kahane et al., 1995; Everett \& Andersen, 1997; Everett et al., 1999; Takahashi et al., 1997).

It has been shown that WSU $86-1044^{\mathrm{T}}$ is morphologically similar to rickettsiae and chlamydiae but is biochemically and antigenically distinct (Dilbeck et al., 1990; Kocan et al., 1990). Two developmental forms (dense bodies and reticulate bodies) of WSU 86-1044 organisms were observed in intracytoplasmic vacuoles by electron microscopy. WSU $86-1044^{\mathrm{T}}$ was completely resistant to penicillin in vitro, whereas all known

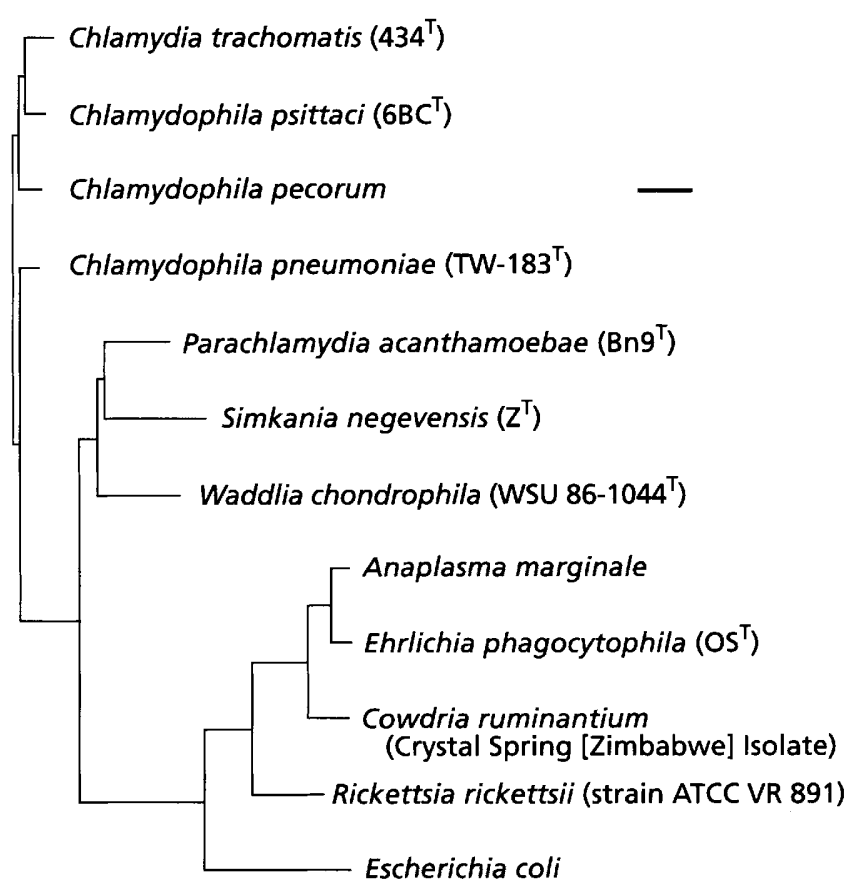

Fig. 1. Dendogram (based on the distances calculated by PILEUP analysis) showing relationship between WSU 86-1044 chlamydiae and rickettsiae. Bar indicates 10 nucleotide substitutions. 
Table 1. Primers for sequencing the rDNA amplicon of WSU $86-1044^{\top}$

\begin{tabular}{|ll|}
\hline Primer & \multicolumn{1}{c|}{ Sequence (postion/source) } \\
\hline Forward & \\
F1 (M13) & 5' GTTTTCCCAGTCACGACGTTGTA (Invitrogen) \\
F2 & 5' GCTCACCAAGGCTAAGACGTC (277-298) \\
F3 & 5' CTAGCTTTGACCTGACGCTGAT (752-774) \\
F4 Reverse & 5' GAATCTGCAACTCGGCTCCATG (1323-1345) \\
R1 (M13) & \\
R1 & 5' TTGTGAGCGGATAACAATTTC (Invitrogen) \\
R2 & 5' CATCCTAAATGCTGGCAAC (392-373) \\
R4 & 5' CACCGCTACATGTGGAATCC (843-822) \\
\hline
\end{tabular}

chlamydia are sensitive (Moulder, 1991). Furthermore, WSU $86-1044^{\mathrm{T}}$ did not react with either polyclonal or monoclonal antibodies used to type chlamydia, although there was some reactivity with antibodies to Chlamydia ruminantium (Dilbeck et al., 1990).

Evolutionary distance values calculated using DISTANCES were used to construct the phylogenetic tree shown in Fig. 1. The tree shows the distinctions between chlamydiae and rickettsiae. Although WSU 86-1044 ${ }^{\mathrm{T}}$, Simkania negevensis and Parachlamydia acanthamoebae formed a cluster, the three are as far apart from one another (84.6-87.2\% sequence similarity) as they are from the chlamydiae.

The genetic data described herein, and the morphological similarity (Kocan et al., 1990), are consistent with a close relationship between WSU $86-1044^{\mathrm{T}}$ and the chlamydiae. However, since rDNA sequence similarity of $>90 \%$ has been suggested as a criterion for classifying chlamydia-like organisms within the same family of the order Chlamydiales (Everett et al., 1999), WSU $86-1044^{\mathrm{T}}$ having $<90 \%$ similarity does not fit into any of the present families in the order Chlamydiales. Therefore, we propose that WSU 86$1044^{\mathrm{T}}$ be classified as Waddliaceae fam. nov., Waddlia chondrophila gen. nov., sp. nov.

\section{Description of Waddliaceae fam. nov.}

Waddliaceae (Wadd'li.a'ce.ae M.L. fem. n. Waddlia the type genus of the family; -aceae ending to denote a family; M.L. fem. pl. Waddliaceae the Waddlia family).

Waddliaceae currently includes the type genus, Waddlia. The description of this family is identical at present to that of 'micro-organism WSU 86-1044' (Dilbeck et al., 1990; Kocan et al., 1990) which are obligate intracellular organisms resistant to penicillin. They grow well in BT producing multiple cytoplasmic vacuoles and Gram-negative, periodic acid-Schiff negative and non-acid-fast inclusions. The inclusions contain coccoid organisms ranging from 0.2 to $0.5 \mu \mathrm{m}$ in size. The BT infectivity is abolished by tetracycline and/or chloroform treatment. The organism multiplies by binary fission and has two developmental forms: the dense form which is infective, and the reticulated form, usually associated with mitochondria, which undergoes binary fission. These organisms do not react with antisera used for typing chlamydiae or rickettsiae. The $16 \mathrm{~S}$ rDNA of the Waddliaceae strains are $>90 \%$ similar to ribosomal genes in WSU $86-1044^{\mathrm{T}}$. The family Waddliaceae belongs to the order Chlamydiales and is a sister taxon of the Chlamydiaceae because the ribosomal genes are $80-90 \%$ similar to ribosomal genes in the Chlamydiaceae. Phylogenetic analyses of the Waddliaceae $16 \mathrm{~S}$ rDNA sequence is presented here. At present this family comprises a single genus, the type genus Waddlia.

\section{Description of Waddlia gen. nov.}

Waddlia [Wadd'li.a. N.L. fem. n. Waddlia arbitrary name derived from the abbreviation WADDL (Washington Animal Disease Diagnostic-Laboratory)].

Members of the genus Waddlia have 16S rDNA that is $>90 \%$ similar to that of the type species, Waddlia chondrophila strain WSU 86-1044 ${ }^{\mathrm{T}}$.

\section{Description of Waddlia chondrophila sp. nov.}

Waddlia chondrophila (chon.dro'phi.la. Gr. n. chondros clump; Gr. adj. philos, - $a$ friendly to; M.L. chondrophila liking clumps, in reference to the association of the organism with cellular mitochondria).

The species Waddlia chondrophila currently includes only the type strain, WSU 86-1044 ${ }^{\mathrm{T}}$ (= ATCC VR $1470^{\mathrm{T}}$ ). Waddlia chondrophila was isolated from the tissues of a first-trimester aborted bovine foetus. The description of this species is identical to that of 'microorganism WSU 86-1044' (Dilbeck et al., 1990; Kocan et al., 1990). The full length of Waddlia chondrophila $16 \mathrm{~S}$ rDNA sequence is $15 \cdot 0 \pm 0 \cdot 25 \%$ different from the 16S rDNA of Chlamydiaceae spp., fitting into the $80-90 \%$ identity range that makes this organism a member of the order Chlamydiales, but not a member of the family Chlamydiaceae. The Waddlia 
chondrophila $16 \mathrm{~S}$ rDNA sequence is $15.8 \%$ different from that of Simkania negevensis strain $\mathrm{Z}^{\mathrm{T}}$, while it is $12.8 \%$ different from that of Parachlamydia acanthamoebae strain $\mathrm{Bn}_{9}{ }^{\mathrm{T}}$, which excludes it from Simkaniaceae and Parachlamydiaceae families of the order Chlamydiales (Everett et al., 1999). For a newly identified strain to be described as a member of Waddliaceae, a nearly full-length rDNA of the new strain may only differ from Waddlia chondrophila $16 \mathrm{~S}$ rDNA by $<10 \%$.

\section{ACKNOWLEDGEMENTS}

We appreciate the help with the GCG Program from Ms Teresa Harkins and Dr Dorothy French, and invaluable assistance from many staff members of WADDL in the process of doing this work. We are particularly indebted to Dr Karin Everett for giving us access to the proposed new classification of the order Chlamydiales before it was published. Our thanks also go to Professor Dr Hans G. Trüper for checking the appropriateness of the name, and to Yvonne McGehee and Jing Cui for preparation of the sequence material.

\section{REFERENCES}

Devereux, J., Haeberli, P. \& Smithies, O. (1984). A comprehensive set of sequence analysis programs for the VAX. Nucleic Acids Res 12, 387-395.

Dilbeck, P. M., Evermann, J. F., Crawford, T. B. \& 7 other authors (1990). Isolation of previously undescribed rickettsia from an aborted bovine fetus. $J$ Clin Microbiol 28, 814-816.

Everett, K. D. E. \& Andersen, A. A. (1997). The ribosomal intergenic spacer and domain 1 of the 23S rRNA gene are phylogenetic markers for Chlamydia spp. Int $J$ Syst Bacteriol 47, 461-473.

Everett, K. D. E., Bush, R. M. \& Andersen, A. A. (1999). Emended description of the order Chlamydiales, proposal of Parachlamydiaceae fam. nov. and Simkaniaceae fam. nov., each containing one monotypic genus, revised taxonomy of the family Chlamydiaceae including a new genus and five new species, and standards for the identification of organisms. Int $J$ Syst Bacteriol 49, 415-440.

Hills, D. M., Mable, B. K., Larson, A., Davis, S. K. \& Zimmer, E. A. (1996). Nucleic acids IV: sequencing and cloning. In Molecular Systematics, 2nd edn, pp. 321-381. Edited by D. M. Hills, C. Moritz \& B. K. Mable. Sunderland, MA: Sinauer.

Kahane, S., Metzer, E. \& Friedman, M. G. (1995). Evidence that the novel microorganism ' $\mathrm{Z}$ ' may belong to a new genus in the family Chlamydiaceae. FEMS Microbiol Lett 126, 203-208.

Kocan, K. M., Crawford, T. B., Dilbeck, P. M., Evermann, J. F. \& McGuire, T. C. (1990). Development of rickettsia isolated from an aborted bovine fetus. $J$ Bacteriol 172, 5949-5955.

Moulder, W. J. (1991). Interaction of chlamydia and host cells in vitro. Microbiol Rev 55, 143-190.

Pearson, W. R. \& Lipman, D. J. (1988). Improved tools for biological sequence comparison. Proc Natl Acad Sci USA 85, 2444-2448.

Roux, V. \& Raoult, D. (1995). Phylogenetic analysis of the genus Rickettsia by $16 \mathrm{~S}$ rDNA sequencing. Res Microbiol 146, 385-396.

Sambrook, J., Fritsch, E. F. \& Maniatis, T. (1989). Molecular Cloning: a Laboratory Manual, 2nd edn. Cold Spring Harbor, NY : Cold Spring Harbor Laboratory.

Swofford, D. L., Olsen, G. J., Waddell, P. J. \& Hills, D. M. (1996). Phylogenetic inference. In Molecular Systematics, 2nd edn, pp. 407-514. Edited by D. M. Hills, C. Moritz \& B. K. Mable. Sunderland, MA: Sinauer.

Takahashi, T., Masuda, M., Tsuruno, T., Mori, Y., Takashima, I., Hiramune, T. \& Kikuchi, N. (1997). Phylogenetic analyses of Chlamydia psittaci strains from birds based on 16S rRNA gene sequence. J Clin Microbiol 35, 2908-2914.

Weisburg, W. G., Hatch, T. P. \& Woese, C. R. (1986). Eubacterial origin of chlamydiae. J Bacteriol 167, 570-574.

White, B. A. (1993). PCR Protocols: Current Methods and Applications. Totowa, NJ: Humana Press.

Wilson, K. H., Blitchington, R. B. \& Greene, R. C. (1990). Amplification of bacterial $16 \mathrm{~S}$ ribosomal DNA with polymerase chain reaction. J Clin Microbiol 28, 942-1946.

Woese, C. R. (1987). Bacterial evolution. Microbiol Rev 51, 221-271. 